\title{
PREGNANCY OUTCOME IN GESTATIONAL DIABETES COMPARED TO BODY MASS INDEX
}

\author{
Senka Sabolović Rudman ${ }^{1}$, Ivka Djaković ${ }^{1}$, Vesna Gall ${ }^{1}$, Željko Djaković $^{2}$ and Vesna Košec ${ }^{1}$
}

${ }^{1}$ Department of Gynecology and Obstetrics, Sestre milosrdnice University Hospital Centre, Zagreb, Croatia; ${ }^{2}$ Jordanovac Department of Thoracic Surgery, Zagreb University Hospital Centre, Zagreb, Croatia

SUMMARY - Gestational diabetes involves disorder of glucose metabolism first diagnosed in pregnancy. Obese women undoubtedly have more often complications in reproductive age, such as fertility difficulties, spontaneous and recurrent miscarriages, premature births, and various obstetric and surgical complications related to the course of pregnancy, delivery and puerperium. Children of obese pregnant women are more likely to develop obesity in childhood and adulthood. We analyzed the outcome of 51 pregnancies in obese pregnant women and 50 pregnant women with normal body mass index. All women in both groups were diagnosed with gestational diabetes by the IADPSG criteria. We analyzed gestational age at delivery and mode of delivery, gestational weight gain, presence of concomitant diagnosis of gestational or chronic hypertension, difference in birth weight, and prevalence of hypertrophic newborns. There was no significant difference in gestational age at pregnancy termination and in the mode of delivery. There was a significant difference in gestational weight gain, number of pregnant women with hypertension, neonatal birth weight and number of hypertrophic children. Based on the data presented, we conclude that obesity is an unfavorable factor for pregnancy outcome. It also influences birth weight and fetal hypertrophy, as well as gestational weight gain.

Key words: Diabetes, gestational; Hypertension, pregnancy-induced; Obesity; Pregnancy outcome; Delivery, obstetric - methods; Birth weight; Hypertrophy

\section{Introduction}

The incidence of obesity increases, entailing increase in obesity related complications in pregnancy ${ }^{1,2}$. In 2009 and 2010, the prevalence of obesity was almost identical in male and female population, about 35 percent $^{3}$. Obese women undoubtedly have more often complications in reproductive age, such as fertility difficulties, spontaneous and recurrent miscarriages, premature births, and various obstetric and surgical complications related to the course of pregnancy, delivery and puerperium ${ }^{1,4}$. Children of obese pregnant women are more likely to develop obesity in childhood and later in life $\mathrm{e}^{5}$.

Correspondence to: Senka Sabolović Rudman, $M D$, PhD, Department of Gynecology and Obstetrics, Sestre milosrdnice University Hospital Centre, Vinogradska c. 29, HR-10000 Zagreb, Croatia E-mail: senka1@rudman.com.hr

Received August 26, 2016, accepted November 20, 2018
Obese pregnant women have a higher incidence of gestational diabetes (GD) and hypertension ${ }^{1,4}$. GD involves disorder of glucose metabolism first diagnosed in pregnancy ${ }^{6}$. The incidence of GD is increasing, represents a risk factor for unfavorable pregnancy outcome and can lead to later complications in the mother and the child ${ }^{7}$. Because these metabolic disorders are often found together, the risk of pregnancy complications is significantly higher ${ }^{1,4}$. These pregnancies require shorter obstetric follow up intervals and detailed antenatal diagnosis, which increases overall costs ${ }^{1,4,8}$.

\section{Subjects and Methods}

We analyzed the outcome of 51 pregnancies in obese pregnant women and 50 pregnant women with normal body mass index (BMI). All women in both groups had a diagnosis of GD by the IADPSG criteria $^{6,9}$. We defined obesity according to the World 
Health Organization classification as BMI $\geq 30 \mathrm{~kg} / \mathrm{m}^{2}$. BMI $18.5-24.9 \mathrm{~kg} / \mathrm{m}^{2}$ was considered normal ${ }^{10}$.

We analyzed gestational age at delivery and mode of delivery, gestational weight gain, presence of concomitant diagnosis of gestational or chronic hypertension, difference in birth weight and frequency of hypertrophic newborns.

Results were statistically analyzed by SPSS 15.0 for Windows, $T$-test and $\chi^{2}$-test.

\section{Results}

Analyzing gestational age at delivery, we found that there were no significant differences between the groups. Two-thirds of pregnant women from both groups gave birth in $38^{\text {th }}$ and $39^{\text {th }}$ week of pregnancy.

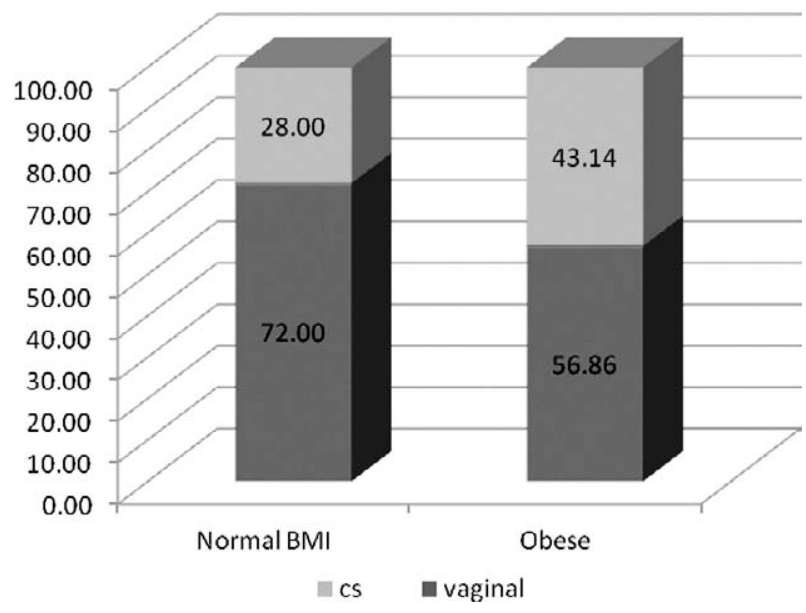

Fig. 1. Comparison of the mode of delivery in women with normal body mass index (BMI) and obese women $(C S=$ cesarean section).

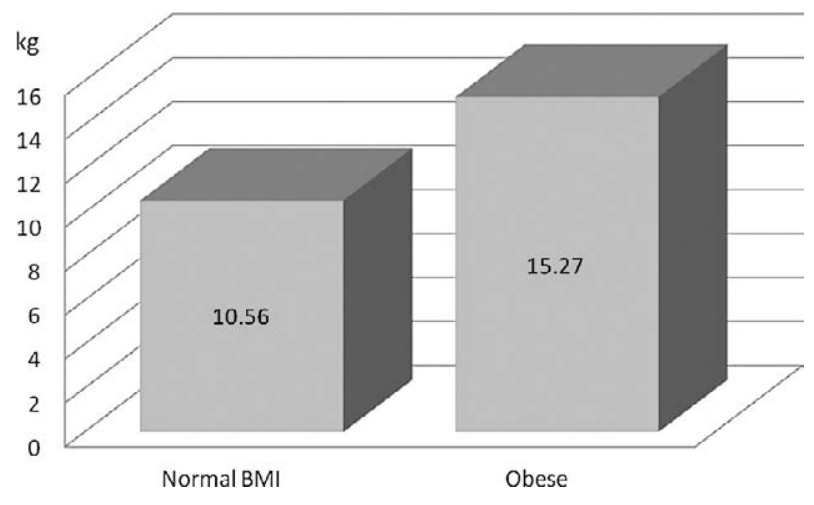

Fig. 2. Comparison of gestational weight gain in women with normal body mass index (BMI) and obese women.

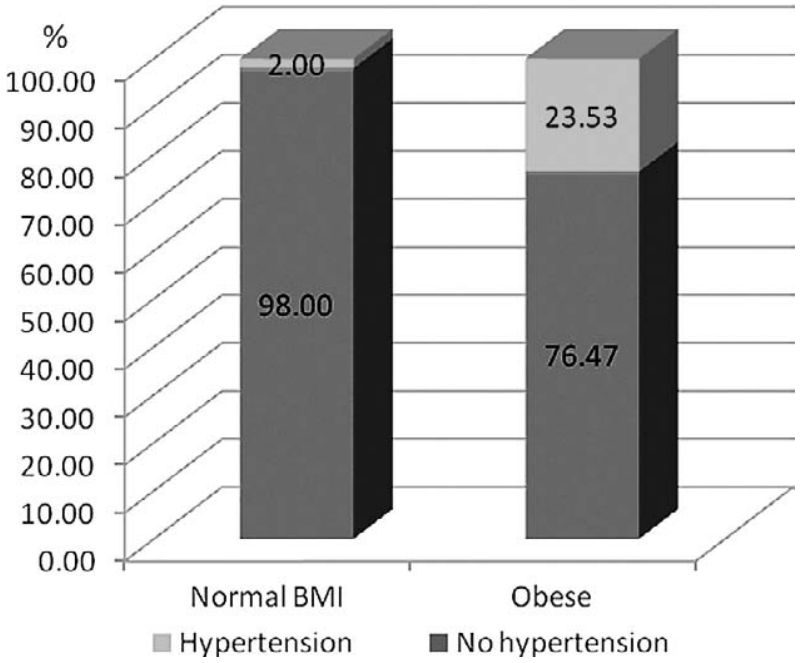

Fig. 3. Presence of hypertension in women with normal body mass index (BMI) and obese women.

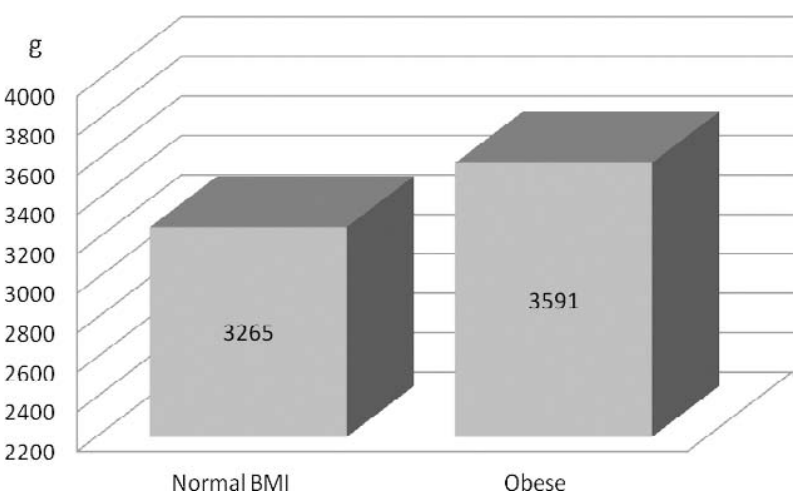

Fig. 4. Comparison of the mean neonatal birth weight in women with normal body mass index (BMI) and obese women.

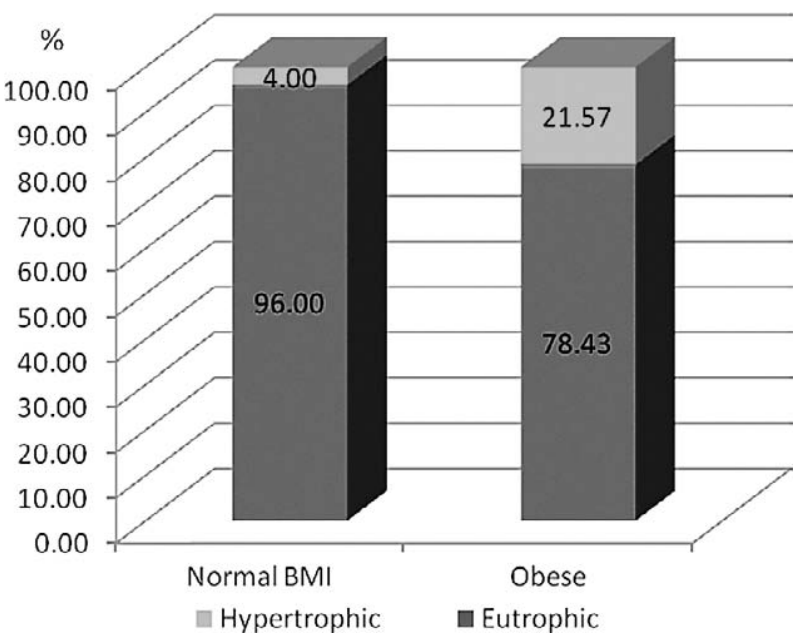

Fig. 5. Hypertrophic newborns in women with normal body mass index (BMI) and obese women. 
There was no significant difference in the mode of delivery between pregnant women with normal BMI and obese women $\left(\chi^{2}=2.52 ; \mathrm{df}=1 ; \mathrm{p}>0.05\right)$ (Fig. 1). Gestational weight gain was significantly higher in the obese group ( $\mathrm{t}=-4.561 ; \mathrm{df}=99 ; \mathrm{p}<0.01)$ (Fig. 2). In the group of obese women, a significant proportion (19.6\%) had the diagnosis of gestational or chronic hypertension. There was a significant difference in the number of pregnant women with hypertension between pregnant women with normal BMI and obese women $\left(\chi^{2}=10.44 ; \mathrm{df}=1 ; \mathrm{p}<0.01\right)$ (Fig. 3 ).

Neonatal birth weight was higher in newborns of obese women as compared with those born to pregnant women with normal body weight $(\mathrm{t}=-3.803$; $\mathrm{df}=99$; $\mathrm{p}<0.01$ ) (Fig. 4). Moreover, in the group of obese pregnant women, there were $21.6 \%$ of hypertrophic newborns, while this figure was only $4 \%$ in the group with normal BMI. There was a significant difference in the rate of neonatal hypertrophy between the two groups $\left(\chi^{2}=6.95 ; \mathrm{df}=1 ; \mathrm{p}<0.01\right)$ (Fig. 5).

\section{Discussion}

In this study, we demonstrated obesity in pregnancy to be associated with an increased risk of many adverse pregnancy outcomes. It is well known that maternal overweight, obesity and severe obesity increase morbidity in both the mother and the newborn, and are associated with a variety of adverse pregnancy outcomes. The prevalence of maternal obesity and GD is increasing and becoming a major health problem in pregnancy with independent and additive impact on obstetric outcome ${ }^{11-13}$. Maternal obesity and GD share common metabolic characteristics such as increased insulin resistance, hyperglycemia and hyperinsulinemia, and GD may elicit distinct effects on clinical outcomes independently of obesity ${ }^{11-13}$. Therefore, examination of the combined association of these common metabolic problems with pregnancy outcome is an important issue.

Demographic data of pregnant women have changed dramatically over the past decade; more women are overweight or obese at conception ${ }^{2}$. Half of patients entering their pregnancy in the US have a BMI $\geq 25.0$ and therefore qualify as overweight or obese ${ }^{11}$. Evidence supports association of excessive gestational weight gain with pregnancy complications and pregnancy outcome, as well as short-term and long-term impacts on neonatal outcome ${ }^{11-13}$. Controversy exists about the amount of how much weight, if any, obese pregnant women should gain ${ }^{14,15}$. The gestational weight gain guidelines were revised and published in 2009 by the Institute of Medicine and recommended a weight gain of 5-9 kg for obese pregnant women ${ }^{16}$. Gestational weight gain recommendations aim to optimize outcomes for the woman and the newborn.

Studies have shown that there is a tendency towards increased weight gain for obese pregnant women ${ }^{11-13}$. Accordingly, our results showed a significantly higher gestational weight gain in the group of obese pregnant women compared to the group with normal BMI. Moreover, gestational weight gain, which is recognized as an independent risk factor for pregnancy related morbidity, was greater than recommended by the Institute of Medicine in obese pregnant women ${ }^{13,17}$.

Studies report a positive correlation between gestational weight gain in obese women and neonatal birthweight ${ }^{11-13,18}$. According to our results, there was a significantly higher proportion of hypertrophic newborns in the group of obese pregnant women and birth weight was also significantly higher in this group. Our results are consistent with the studies reporting a connection between maternal obesity and fetal outcome $^{11-13,18}$. Moreover, studies have shown that newborns of obese women who gained more than recommended weight during pregnancy also had a higher rate of meconium stained amniotic fluid, neonatal hypoglycemia and congenital malformations, but this was not the subject of our research ${ }^{12,18}$.

According to numerous studies, maternal obesity is associated with higher cesarean section rates ${ }^{18-20}$. In our study, we did not determine association between obesity and mode of delivery. This can be explained by the fact that the control group consisted of pregnant women with normal BMI and GD, which may be also associated with a higher incidence of cesarean section. This is in accordance with the observation of Zilberlicht et al., who report higher BMI, maternal hyperglycemia and recommended gestational weight gain as independent risk contributors to adverse pregnancy outcome $^{21}$. Furthermore, there is a mutual effect of these three factors on adverse outcomes ${ }^{21}$. Numerous studies found connection between maternal obesity and a higher rate of gestational hypertension ${ }^{12,18,20,22}$. Our results are consistent with the studies reporting a connection between maternal obesity and gestational hypertension ${ }^{12,18,20,22}$. This is in accordance with the observation of Scifres et al., who evaluated the associa- 
tion of obesity with pregnancy outcome in women with GD. According to their results, obesity was independently associated with a higher incidence of gestational hypertension and hypertensive disorders of pregnancy were significantly increased in obese women with weight gain higher than recommended when compared with obese women with less weight gain $^{22}$.

\section{Conclusion}

Based on the data presented, we conclude that obesity is an unfavorable factor for pregnancy outcome. It also influences gestational weight gain, as well as neonatal birth weight and fetal hypertrophy.

\section{References}

1. Ivanišević M, Kosi N, Đelmiš J, Juras J. Pregnancy, delivery and puerperium in obese women. Gynaecol Perinatol. 2015;24(3): 89-98.

2. Vraneš HS, Djaković I. Length and weight of newborns in Croatia from 1985 to 2009. Wien Klin Wochenschr. 2015;127 (17-18):685-90. http://dx.doi.org/10.1007/s00508-014-0686-2.

3. Cunningham FG, Leveno KJ, Bloom SL, Spong CY, Dashe JS, Hoffman BL, et al. Obesity. In: Cunningham FG, Leveno KJ, Bloom SL, Spong CY, Dashe JS, Hoffman BL, Casey BM, Sheffield JS, editors. Williams Obstetrics. New York: McGraw Hill Education, 2014;961-72.

4. Đelmiš J, Pavić M, Ivanišević M, Juras J, Herman M, Orešković S. Body mass index and pregnancy outcome. Gynaecol Perinatol. 2015;24(3):99-105.

5. Finer S. Fetal programming via maternal diabetes: the controversy continues. Diabet Med. 2015;32(3):291-4. http://dx.doi. org/10.1111/dme.12675.

6. Đelmiš J, Ivanišević M, Juras J, Herman M. Diagnosis of hyperglycemia in pregnancy. Gyneacol Perinatol. 2010;19(2): 86-9.

7. Djaković I, Sabolović Rudman S, Gall V, Košec A, Markuš Sandrić M, Košec V. Do changing diagnostic criteria for gestational diabetes influence pregnancy outcome? Acta Clin Croat. 2016;55(3):422-7.

http://dx.doi.org/10.20471/acc.2016.55.03.11.

8. Aktulay A, Engin-Ustun Y, Ozkan MS, Erkaya S, Kara M, Kaymak O, Danisman N. Gestational diabetes mellitus seems to be associated with inflammation. Acta Clin Croat. 2015; 54(4):475-8.

9. International Association of Diabetes and Pregnancy Study Groups. International Association of Diabetes and Pregnancy Study Groups recommendations on the diagnosis and classification of hyperglycemia in pregnancy. Diabetes Care. 2010; 33:676-82. http://dx.doi.org/10.2337/dc09-1848.
10. WHO, Obesity: Preventing and Managing the Global Epidemic, Vol. 894 of WHO Technical Report Series, World Health Organization, Geneva, Switzerland, 2000.

11. Maier JT, Schalinski E, Gauger U, Hellmeyer L. Antenatal body mass index (BMI) and weight gain in pregnancy - its association with pregnancy and birthing complications. J Perinat Med. 2016;44(4):397-404. http://dx.doi.org/10.1515/jpm-2015-0172.

12. Maayan-Metzger A, Schushan-Eisen I, Strauss T, Globus O, Leibovitch L. Gestational weight gain and body mass indexes have an impact on the outcomes of diabetic mothers and infants. Acta Paediatr. 2015;104(11):1150-5. http://dx.doi. org/10.1111/apa.13166.

13. Gante I, Amaral N, Dores J, Almeida MC. Impact of gestational weight gain on obstetric and neonatal outcomes in obese diabetic women. BMC Pregnancy Childbirth. 2015;15:249. http://dx.doi.org/10.1186/s12884-015-0692-z.

14. Margerison Zilko CE, Rehkopf D, Abrams B. Association of maternal gestational weight gain with short- and long-term maternal and child health outcomes. Am J Obstet Gynecol. 2010; 202(6):574.e1-8. http://dx.doi.org/10.1016/j.ajog.2009.12.007.

15. American College of Obstetricians and Gynecologists. ACOG Committee opinion no. 548: Weight gain during pregnancy. Obstet Gynecol. 2013;121(1):210-2. http://dx.doi.org/10.1097/01.AOG.0000425668.87506.4c.

16. Institute of Medicine (US) and National Research Council (US) Committee to Reexamine IOM Pregnancy Weight Guidelines; Rasmussen KM, Yaktine AL, editors. Weight Gain during Pregnancy: Reexamining the Guidelines. Washington (DC): National Academies Press (US); 2009.

17. Narayanan RP, Weeks AD, Quenby S, Rycroft D, Hart A, Longworth $\mathrm{H}$, et al. Fit for birth - the effect of weight changes in obese pregnant women on maternal and neonatal outcomes: a pilot prospective cohort study. Clin Obes. 2016;6(1):79-88. http://dx.doi.org/10.1111/cob.12129.

18. Dennedy MC, Avalos G, O'Reilly MW, O'Sullivan EP, Dunne FP. The impact of maternal obesity on gestational outcomes. Ir Med J. 2012;105(5 Suppl):23-5.

19. Al-Kubaisy W, Al-Rubaey M, Al-Naggar RA, Karim B, Mohd Noor NA. Maternal obesity and its relation with the cesarean section: a hospital based cross sectional study in Iraq. BMC Pregnancy Childbirth. 2014;14:235.

http://dx.doi.org/10.1186/1471-2393-14-235.

20. Marchi J, Berg M, Dencker A, Olander EK, Begley C. Risks associated with obesity in pregnancy, for the mother and baby: a systematic review of reviews. Obes Rev. 2015;16(8):621-38. http://dx.doi.org/10.1111/obr.12288.

21. Zilberlicht A, Feferkorn I, Younes G, Damti A, Auslender R, Riskin-Mashiah S. The mutual effect of pregestational body mass index, maternal hyperglycemia and gestational weight gain on adverse pregnancy outcomes. Gynecol Endocrinol. 2016;32 (5):416-20. http://dx.doi.org/10.3109/09513590.2015.1127911.

22. Scifres C, Feghali M, Althouse AD, Caritis S, Catov J. Adverse outcomes and potential targets for intervention in gestational diabetes and obesity. Obstet Gynecol. 2015;126(2):316-25. http://dx.doi.org/10.1097/AOG.0000000000000928. 


\section{Sažetak \\ ISHOD TRUDNOĆE UZ GESTACIJSKI DIJABETES U USPOREDBI S INDEKSOM TJELESNE MASE}

\section{S. Sabolović Rudman, I. Djaković, V. Gall, Ž. Djaković i V. Košec}

Gestacijski dijabetes podrazumijeva poremećaj metabolizma glukoze koji se prvi puta dijagnosticira u trudnoći, a njegova incidencija je u porastu. Pretile žene nedvojbeno imaju češće probleme i komplikacije u reproduktivnim godinama, što podrazumijeva teškoće pri zanošenju, spontane i habitualne pobačaje, prijevremene porođaje i različite opstetričke i kirurške komplikacije vezane za tijek trudnoće, porođaja i babinja. Djeca iz takvih trudnoća češće razvijaju pretilost u djetinjstvu kao i u odrasloj dobi. S obzirom na navedeno analizirali smo ishod trudnoća u 51 pretile trudnice i 50 trudnica s urednim indeksom tjelesne mase, pri čemu su sve trudnice (u objema skupinama) imale dijagnozu gestacijskog dijabetesa prema kriterijima IADPSG. Analizirali smo gestacijsku dob, način dovršenja trudnoće, prirast na težini trudnica, prisutnost istodobnih dijagnoza gestacijske ili kronične hipertenzije, razliku u težini novorođenčadi te učestalost hipertrofične novorođenčadi. Rezultati su pokazali da ne postoji statistički značajna razlika u gestacijskoj dobi kad je završena trudnoća niti u načinu dovršenja porođaja. Utvrđena je statistički značajna razlika u dobivenim kilogramima tijekom trudnoće, broju trudnica s hipertenzijom, porođajnoj masi novorođenčadi i broju hipertrofične djece. U zaključku, pretilost u trudnoći s gestacijskim dijabetesom je nepovoljan čimbenik za ishod trudnoće, porođajnu masu i prekomjeran rast novorođenčadi, kao i za prirast tjelesne mase trudnice tijekom trudnoće.

Ključne riječi: Dijabetes, gestacijski; Hipertenzija uzrokovana trudnoćom; Pretilost; Trudnoća, ishod; Porođaj-metode; Porođajna težina; Hipertrofija 